\title{
Bio-Morphological Characters of Alien Legume Species, Influencing Their Invasion in Natural Plant Communities
}

\author{
Yulia Vinogradova \\ Main Botanical Garden, Moscow, Russia \\ Email: gbsad@mail.ru
}

How to cite this paper: Vinogradova, Y. (2016) Bio-Morphological Characters of Alien Legume Species, Influencing Their Invasion in Natural Plant Communities. American Journal of Plant Sciences, 7, 2390-2398

http://dx.doi.org/10.4236/ajps.2016.716209

Received: September 14, 2016

Accepted: November 26, 2016

Published: November 29, 2016

Copyright $\odot 2016$ by author and Scientific Research Publishing Inc. This work is licensed under the Creative Commons Attribution International License (CC BY 4.0).

http://creativecommons.org/licenses/by/4.0/

\begin{abstract}
Five alien legume species, actively invading in natural plant communities in European part of Russia, were studied-Lupinus polyphyllus Lindl., Galega orientalis Lam., Robinia pseudoacacia L., Amorpha fruticosa L. and Caragana arborescens L. Distribution ranges (considering their invasive status) were mapped. Not a single bio-morphological character to forecast invasion success in natural plant communities within secondary distribution range was found. The data of key value/importance for explaining invasive success of the species studied were obtained. Two hypotheses-Propagule Pressure and Evolution of Invasiveness-were critically analyzed in view of the received data.
\end{abstract}

\section{Keywords}

Alien Species, Weeds, Legumes, Lupinus, Galega, Robinia, Amorpha, Caragana, Invasion, Propagule Pressure Hypothesis, Evolution of Invasiveness Hypothesis

\section{Introduction}

Human activity seriously transformed natural ecosystems particularly in consequence of intentional transfer of plant species from their natural distribution range to new habitats. Many of the most aggressive alien plant species invaded in natural communities and caused significant changes in structure and functioning of the latter. Those species are treated as invasive group of species. There are many hypotheses which attempt to explain the phenomenon of invasiveness [1] [2].

Invasive species influence natural plant communities in different ways. They could reduce a number of indigenous species and their abundance, change soil and hydrogeological conditions; invasive species often hybridize with natural ones, etc. 
Full and detailed classifications, defining the impact of non-native species were recently published [3] [4]. The following impact classes were designated: competition, hybridization, transmission of the diseases to natural species, poisoning/toxicity, bio-fouling, etc. Thus, in majority of cases the influence of an alien species in natural communities is a complex phenomenon, comprising a few impact factors simultaneously.

Legumes (Fabaceae/Leguminosae) are one of the leaders in harmful consequences of plant invasions. The family is on 4th place in Europe in number of alien species (323 in total, 181 naturalizing [5]). In the Middle Russia legumes occupy the 5th place in a number of alien species (79 in total, 43 naturalizing [6]). Aggressiveness of the legume species could be explained by their mass usage in agriculture as forage grass/soilage as well as soil fertility boosters. Benevolent intentions soon demonstrate the opposite side of "environmental improvement": invading in a habitat, lacking nitrogenous compounds, the legume species fertilize soil with nitrogen, making it suitable for other alien weeds. Since all the changes occur at the level of ecosystem even a complete elimination of the invasive legume species wouldn't return the community to its initial ("before-invasion") status.

Within the last 20 year the alien fraction of flora of the Middle Russia gained 80 new species of Fabaceae. About 20 of them were brought purposeless/accidentally, 30 are increasing their natural distribution range to the North, the other 30 are represented by the species escaped from cultivation. The most aggressive invasive legume species belong to the third group-Lupinus polyphyllus Lindl., Galega orientalis Lam. and Robinia pseudoacacia L., as well as actively naturalizing and potentially invasive Amorpha fruticosa L. and Caragana arborescens $\mathrm{L}$. Those five species are still widely cultivated so we expect a further increasing of their secondary distribution range and invasive status [6].

In this paper the results of biological study of the most aggressive alien legume species in the Middle Russia are presented. We undertook an attempt to explain a success of those species' invasion in natural and semi-natural plant communities of the region.

The following tasks were accomplished: a) trends in changes of status for model species were revealed; b) schemes of distribution ranges were compiled to forecast the species' further expansion; c) a comparative analysis of bio-morphological characters of the model invasive and closely-related non-naturalizing species was performed; d) the hypotheses, explaining invasive success of plants species within secondary distribution range were tested; the arguments in favour of Propagule Pressure and Evolution of Invasiveness hypotheses are presented.

\section{Material and Methods}

According to invasive potential of the species the following four groups are recognized [7] [8] [9]:

- Status 1. Transformers;

- Status 2. Alien species, actively spreading and becoming naturalized within disturbed, semi-natural and natural habitats; 
- Status 3. Alien species, spreading and undergoing naturalization in disturbed habitats; in the course of further naturalization, some of them will apparently be integrated in semi-natural and natural communities;

- Status 4. Potentially invasive species, capable of reproduction in impact habitats or demonstrating invasive potential in adjacent regions.

It is worth mentioning, that one and the same species could be attributed to different statuses in different regions (Figure 1).

Data on the mentioned above invasive statuses are provided by the local researchers from 25 administrative regions of the European territory of Russia. Territory area is $3,960,000 \mathrm{~km}^{2}$ ( $40 \%$ of all Europe)-from $70^{\circ} 00^{\prime} \mathrm{N}$ to $41^{\circ} 13^{\prime} \mathrm{N}$ and from $19^{\circ} 38^{\prime} \mathrm{W}$ to $66^{\circ} 11^{\prime} \mathrm{W}$.

Characters' detecting was carried out in two directions: 1) comparison of bio-morphological characters of the invasive and closely-related non-naturalizing species; 2) comparison of bio-morphological characters of one and the same species in within natural and secondary distribution ranges. The first route comprised comparisons of the invasive species from North America Lupinus polyphyllus with the cultivated $L$. angustifolius L.; the naturalizing Caragana arborescens with the cultivated C. laeta Kom., the invasive Galega orientalis with the cultivated $G$. officinalis L.; the invasive (in many regions) Robinia pseudoacacia with the cultivated Robinia $x$ ambigua Poir. The second route is presented by comparison of Galega orientalis characters within natural and secondary distribution ranges. All species were identificated by the author of this article.

For each species $10+$ populations from secondary distribution range were studied. Detailed data on individual populations were published earlier [6]. In this paper we present averaged data in table form for all the species, also indicating morphometric amplitudes of the characters.

The following characters were studied:

- biomass of above-ground organs and assimilating surface; leaves' surface; number of leaves per shoot and number of shoots per plant;

- permanent flowering/fruitng capacity
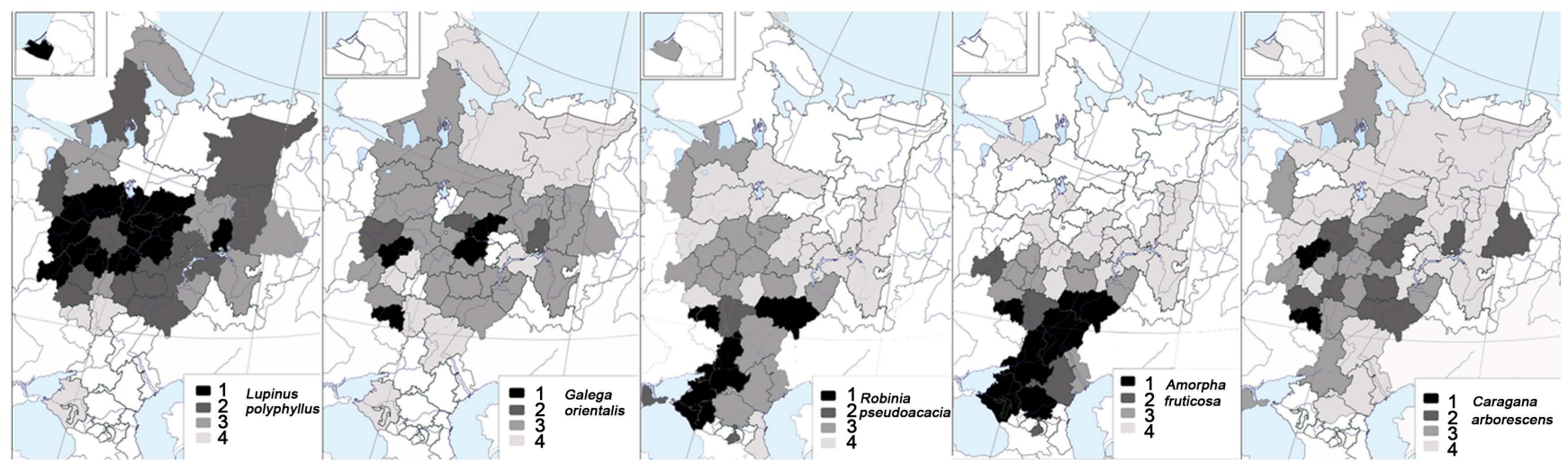

Figure 1. Secondary distribution ranges in different regions of the European territory of Russia. 1: Status 1, 2: Status 2, 3: Status 3, 4: Status 4 . 
- androecium capability, allowing/not allowing two anthesis periods for individual flower;

- morphometric characters: flowers size, beans length, seed weight, pollen-grain size;

- pollen fertility;

- duration of main phenological phases; capability of early seeding/seed production;

- seed production: number of flowers per inflorescence; number of beans per infructescence/per plant; number of fertile seeds per bean;

- germinating capacity of scarified and non-scarified seeds; seedling vigor; seed sprouting duration; seedlings growth dynamics within the first year;

- vegetative propagation capabilities;

- steadiness to pests and diseases;

- population density;

- cultigeneous distribution range.

The morphometric characteristics were determined using a Keyence VHX_1000 E digital microscope. Pollen fertility was detected by staining pollen grains with acetocarmine with insignificant heating with subsequent viewing of slides in five fields of view of the microscope. The results were processed statistically using Microsoft Excel and the Past software package.

\section{Results and Discussion}

All the five taxa studied are on the list of 50 most actively distributing/naturalizing species in the European part of Russia. Lupinus polyphyllus is on 18th place, Caragana arborescens-on 28th, Galega orientalis-on 32d, Robinia pseudoacacia and Amorpha fruticosa share 47-48th places (Table 1).

An attempt to detect one character, determining invasive activity of alien legume species failed. e.g., Lupinus polyphyllus has got a competitive advantage against closelyrelated $L$. angustifolius in more numerous beans and number of seeds per plant, larger leaf surface (both, of individual leaflet and general surface of compound leaf), more numerous flowers per inflorescence and androecium capability, allowing two anthesis periods for individual flower [8] [9]. L. polyphyllus has a vegetative propagation capacity, L. angustifolius is an annual. Thus, in another few characters $L$. polyphyllus is inferior to L. angustifolius, having smaller beans and seeds, smaller number of lateral shoots and leaves per shoot which results in less assimilating surface. Both species got high pollen fertility and germinating capacity of scarified seeds (Table 2).

Table 1. Invasive statuses of 5 legume species in the European territory of Russia.

\begin{tabular}{|c|c|c|c|c|c|}
\hline \multirow{2}{*}{ Status } & \multicolumn{4}{|c|}{ Number of regions where the species belongs to the status } & \multirow{2}{*}{ Total regions number } \\
\hline & 1 & 2 & 3 & 4 & \\
\hline Lupinus polyphyllus & 10 & 3 & 2 & 4 & $19(76 \%)$ \\
\hline Caragana arborescens & 2 & 4 & 6 & 5 & $17(68 \%)$ \\
\hline Galega orientalis & 3 & 2 & 9 & 2 & $16(64 \%)$ \\
\hline Robinia pseudoacacia & 4 & 3 & 4 & 2 & $13(52 \%)$ \\
\hline Amorpha fruticosa & 4 & 2 & 2 & 5 & $13(52 \%)$ \\
\hline
\end{tabular}


Table 2. Comparison of bio-morphological characters in four herbaceous legume species.

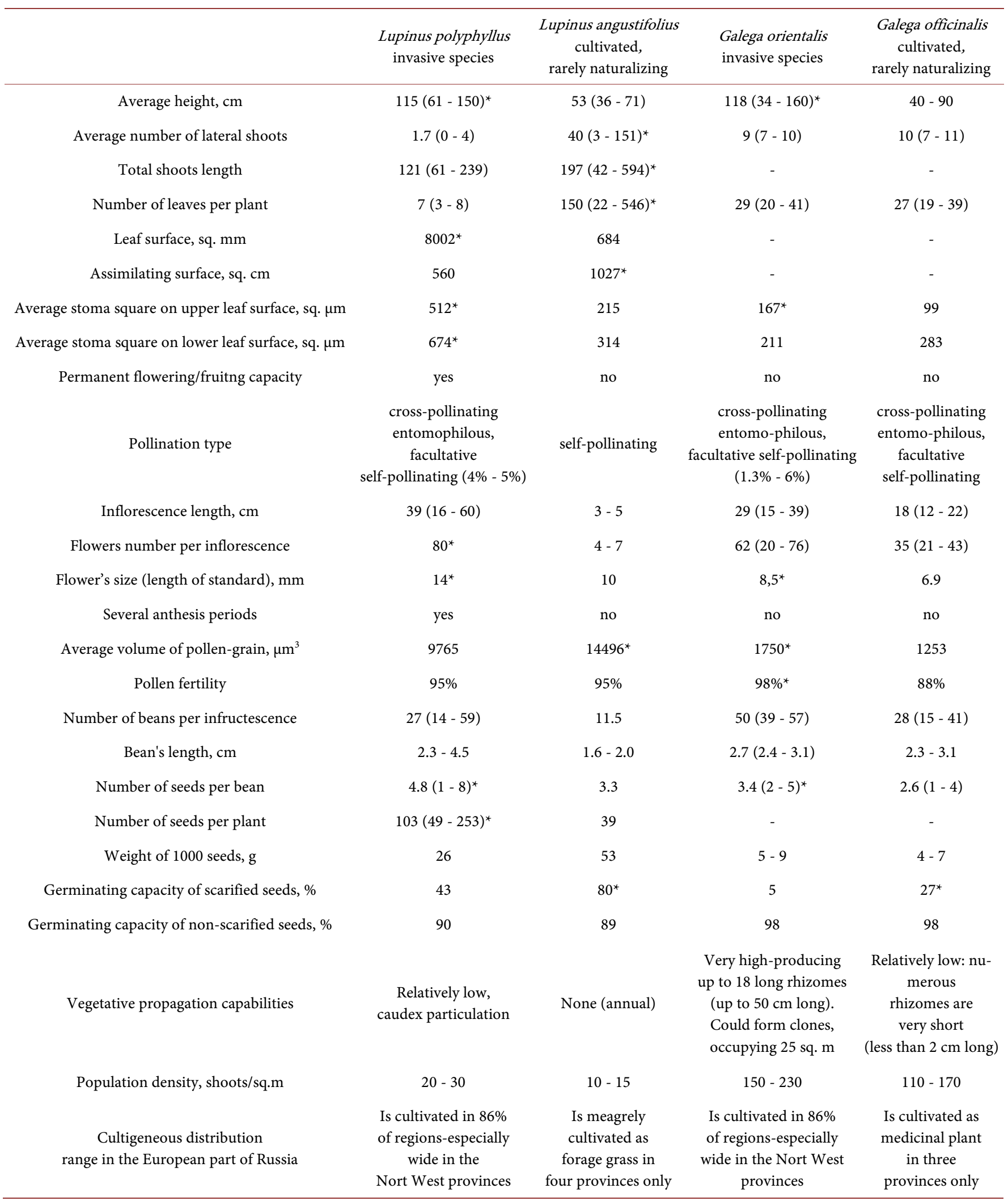

${ }^{*}$ characters, proving competitive advantages of the species (statistically significant difference). -: there is no information. 
Galega orientalis has got competitive advantage against closely-related $G$. officinalis in more numerous flowers and seeds per inflorescence, higher pollen fertility, vegetative propagation capabilities and higher population density [10]. The main characteristic feature of Galega orientalis is its cultigeneous distribution range, far exceeding the one for $G$. officinalis. From the other side $G$. orientalis is inferior to $G$. officinalis in number of lateral shoots per plant and germinating capacity of scarified seeds. There are no significant differences in number of leaves per generative shoot, bean length, number of seeds per bean, structure \& development of generative sphere (excluding its smaller sizes in $G$. officinalis) between these species.

Invasive Robinia pseudoacacia (Table 3 ) has got competitive advantage against cultivated $R . \times$ ambigua in number of seeds per bean, number of flowers/fruits per inflorescence, slightly larger pollen-grains and significantly ( 2.5 times) higher pollen fertility [11]. From the other side $R . \times$ ambigua flowers and fruits a few times within one

Table 3. Comparison of bio-morphological characters in six legume species (trees \& shrubs).

\begin{tabular}{|c|c|c|c|c|c|c|}
\hline & Robinia pseudoacacia & Robinia $\times$ ambigua & Amorpha fruticosa & A. paniculata & $\begin{array}{c}\text { Caragana } \\
\text { arborescens }\end{array}$ & C. laeta \\
\hline Flowering behavior & Rare second flowering & $\begin{array}{l}{ }^{*} \text { Flowers and } \\
\text { fruits few } \\
\text { times per season }\end{array}$ & ${ }^{\star}$ Flowers end-June & Flowers mid-July & ${ }^{\star}$ Mass flowering & Solitary flowers \\
\hline Inflorescence length, cm & $5.2-15.5$ & $5-12$ & $11-18$ & $9-14$ & In clusters & Solitary flowers \\
\hline $\begin{array}{l}\text { Flowers number } \\
\text { per inflorescence }\end{array}$ & $8-31$ & $20-25$ & $\sim 100^{*}$ & $\sim 40$ & $10^{*}$ & $\sim 0$ \\
\hline $\begin{array}{c}\text { Flower's size } \\
\text { (length of standard), } \mathrm{mm}\end{array}$ & $15.4-19.5$ & $19.3-22^{*}$ & $6.1-6.3$ & 5.2 & $17-19$ & $28^{*}$ \\
\hline $\begin{array}{l}\text { Average volume } \\
\text { of pollen-grain, } \mu \mathrm{m}^{3}\end{array}$ & 7484 & 7854 & 3089 & 3259 & $3239^{*}$ & 1925 \\
\hline Pollen fertility, \% & $69-98^{*}$ & 38 & $99^{*}$ & 61 & $93-96$ & 96 \\
\hline $\begin{array}{c}\text { Fruits number } \\
\text { per infructescence }\end{array}$ & $4.4-7.8^{*}$ & $1-2$ & $124(40-224)^{\star}$ & 19.6 & $3.9(1-7)^{*}$ & 0 \\
\hline Bean length, $\mathrm{cm}$ & $4-6(2.1-10.7)$ & $5.6(3-8)$ & $0.6-0.8$ & 0.8 & $4.4(2.5-6)$ & $3.6(2.6-4.6)$ \\
\hline Number of seeds per bean & $3.8(1-12)^{*}$ & $2.2(1-6)$ & 1 & 1 & $2.4(1-8)^{*}$ & $1.6(1-3)$ \\
\hline $\begin{array}{c}\text { Vegetative propagation } \\
\text { capabilities }\end{array}$ & $\begin{array}{l}\text { High-actively } \\
\text { producing coppice } \\
\text { shoots \& root } \\
\text { sprouts and forming } \\
\text { clones up to } 90 \text { sq. m }\end{array}$ & $\begin{array}{l}\text { Weak-producing } \\
\text { root sprouts }\end{array}$ & $\begin{array}{c}\text { High-actively } \\
\text { producing root } \\
\text { sprouts and forming } \\
\text { large clones. } \\
\text { Adventitious root } \\
\text { system well developed }\end{array}$ & $\begin{array}{c}\text { Weak-producing } \\
\text { few root } \\
\text { sprouts only }\end{array}$ & $\begin{array}{l}\text { High-actively } \\
\text { producing root } \\
\text { sprouts, but clones } \\
\text { are not massive }\end{array}$ & $\begin{array}{c}\text { None-root } \\
\text { sprouts not } \\
\text { recorded } \\
\text { in the Main } \\
\text { Botanical Garden) }\end{array}$ \\
\hline Population density & 2000 trees per hectare & $\begin{array}{l}\text { Solitary trees in } \\
\text { planting spots }\end{array}$ & $\begin{array}{l}5 \text { shrub } \\
\text { per sq. m }\end{array}$ & $\begin{array}{l}\text { Solitary shrubs } \\
\text { in planting spots }\end{array}$ & $\begin{array}{l}1 \text { shrub } \\
\text { per sq. m }\end{array}$ & $\begin{array}{l}\text { Solitary shrubs in } \\
\text { planting spots }\end{array}$ \\
\hline $\begin{array}{l}\text { Cultigeneous } \\
\text { distribution range in the } \\
\text { European part of Russia }\end{array}$ & $\begin{array}{l}\text { Mass cultivation } \\
\text { in } 86 \% \text { of regions, } \\
\text { especially wide in } \\
\text { wood lines within } \\
\text { South West provinces }\end{array}$ & $\begin{array}{l}\text { Solitaires and park- } \\
\text { ways in big cities }\end{array}$ & $\begin{array}{l}\text { Mass cultivation in } \\
73 \% \text { of regions, } \\
\text { especially wide in } \\
\text { wood lines within } \\
\text { South East provinces }\end{array}$ & $\begin{array}{c}\text { Botanical } \\
\text { gardens only }\end{array}$ & $\begin{array}{c}\text { Mass cultivation } \\
\text { in } 83 \% \text { of regions, } \\
\text { especially wide } \\
\text { in wood lines }\end{array}$ & $\begin{array}{c}\text { Botanical } \\
\text { gardens only }\end{array}$ \\
\hline
\end{tabular}

${ }^{*}$ characters, proving competitive advantages of the species (statistically significant difference). 
season whereas reflorescence occurs in $R$. pseudoacacia not every autumn (and fruit inception does not happen at all).

Amorpha fruticosa has got competitive advantage against cultivated $A$. paniculata and $A$. californica in earlier phenological phases, higher seed production, seed germination capacity, earlier seed sprouting, seedlings growth dynamics within the first year and significantly larger cultigeneous distribution range.

Caragana arborescens has got competitive advantage against closely-related $C$. arborescens $\mathrm{f}$. lorbergii and $C$. laeta in larger pollen-grains, more numerous flowers per inflorescence, much higher seed germination capacity and long-standing cultivating tradition, resulting in significantly larger secondary distribution range. Thus, Central Asian C. laeta has larger flowers [12].

While comparing the plants of $G$. orientalis from natural and secondary distribution ranges we obtained data, supporting the Evolution of Increased Competitive Ability hypothesis (Evolution of Increased Competitive Ability-EICA; Blossey and Notzold [13]). Invasive phenotype appeared more "powerful" than the natural one: biomass of above-ground organs, inflorescence length, number of flowers/fruits per plant and seed production exceed significantly within the secondary distribution range.

Thus, for all the compared pairs of species the invasive ones have competitive advantage against closely-related non-invasive ones in more numerous flowers/fruits in raceme and denser populations.

Invasive species also far exceed non-naturalizing ones in area of cultigeneous distribution range. Invasive activity of one and the same species in different regions within secondary distribution range varies greatly which is determined by both, the natural and antropogenic factors: species invade more actively in natural plant communities within the regions where they have been widely cultivating for a long period of time.

Therefore I assume that the Propagule Pressure Hypothesis works better for explaining a success of invading the most aggressive legume species in natural phytocenoses. According to that hypothesis some invasive species produce big amount of seeds, which increase the species invasive potential. Thereby already in the next generation after expansion start the species could be qualified as "strong invasive species" [14] and its distribution control becomes extremely difficult task by default.

Although, that would be reasonable to insert additions to statement of the hypothesis, allowing to consider not only seed production of the individual plant but also density of the naturalizing populations and area of cultigeneous distribution range. Reformulated hypothesis could look like follows: "The level of natural communities' invasibility is determined by a number and abundance of invading alien plant species which in its turn depends not only upon the number of diaspores, produced by individual plant but also upon density of the naturalizing populations and area of cultigeneous distribution range".

Besides that, the term "propagule pressure" comprises not only direct meaningmass invasion of alien plants into natural ecosystems-but also higher probability of new genotypes appearing as a result of mutations and/or recombinations of numerous 
genomes. Increased genetic diversity in naturalizing populations stimulates appearance of larger number of genotypes, "pressing" the natural communities. In that respect the Propagule Pressure Hypothesis aligns with the Evolution of Invasiveness Hypothesis [13] [15] which considers fast evolution of genetic characters in successful invasive species, tightly connected with natural selection pressure in new environment.

\section{Conclusions}

There is no single/exclusive bio-morphological character which could be used for predicting invasive success of any alien legume species within the secondary distribution range.

The main reason for invasion of the studied species into natural phytocenoses of the Middle Russia is their wide cultivation, ignoring proper agrotechnology and large waste-lands areas. Thereby, the Propagule Pressure Hypothesis with some additions (population density, area of cultigeneous distribution range) suits best for explaining the invasive species' success.

The Propagule Pressure Hypothesis should be considered in inextricable connection with the Evolution of Invasiveness Hypothesis, because high number of diaspores assumes higher probability of new (and better adapted to new environment conditions) genotypes' appearance as a result of mutations and/or recombinations of numerous genomes

\section{Acknowledgements}

I'm grateful to Dr. Michael Serebryanyi for valuable comments, discussion and translating the text of the paper to English.

This work was partly supported by the grant of Russian Fund for Fundamental Research № 15-29-02556.

\section{References}

[1] Williamson, M. (1996) Biological Invasions. Chapman \& Hill, London.

[2] Richardson, D.M. and Pyšek, P. (2006) Plant Invasions: Merging the Concepts of Species Invasiveness and Community Invasibility. Progress in Physical Geography, 30, 409-431. http://dx.doi.org/10.1191/0309133306pp490pr

[3] Blackburn, T.M., Essl, F., Hulme, Ph., Jeschke, J.M., Kuhn, I., Kumschick, S., Markova, Z., Mrugala, A., Nentwig, W., Pergl, J., Pysek, P., Rabitsch, W., Riccardi, A., Richardson, D.M., Sendek, A., Vila, M., Wilson, J.R.U., Winter, M., Genovesi, P. and Bacher, S. (2014) A Unified Classification of Alien Species Based on the Magnitude of their Environmental Impacts. PLOS Biology, 12, 1-11. http://dx.doi.org/10.1371/journal.pbio.1001850

[4] Jeschke, J.M., Bacher, S., Blackburn, T.M., Dick, J.T.A., Essl, F., Evans, T., Gaertner, M., Hulme, Ph., Kuhn, I., Mrugala, A., Pergl, J., Pysek, P., Rabitsch, W., Riccardi, A., Richardson, D.M., Sendek, A., Vila, M., Winter, M. and Kumschick, S. (2014) Defining the Impact of Non-Native Species. Conservation Biology, 28, 1189-1194.

[5] Lambdon, P.W., Pyšek, P., Basnou, C., Hejda, M., Arianoutsou, M., Essl, F., Jarošík, V., Pergl, J., Winter, M., Anastasiu, P., Andriopoulos, P., Bazos, I., Brundu, G., Celesti-Grapow, L., Chassot, P., Delipetrou, P., Josefsson, M., Kark, S., Klotz, S., Kokkoris, Y., Kühn, I., 
Marchante, H., Perglová, I., Pino, J., Vila, M., Zikos, A., Roy, D. and Hulme, Ph. (2008) Alien Flora of Europe: Species Diversity, Temporal Trends, Geographical Patterns and Research Needs. Preslia, 80, 101-149.

[6] Vinogradova, Yu.K., Kuklina, A.G. and Tkacheva, E.V. (2014) Invasive Legumes-Lupinus, Galega, Robinia, Amorpha, Caragana. ABF, Moscow (in Russian).

[7] Pyšek, P., Richardson, D.M., Rejmánek, M., Webster, G.L., Willamson, M. and Kirschner, J. (2004) Alien Plant in Checklist and Floras: Towards Better Communication between Taxonomists and Ecologists. Taxon, 53, 131-143.

[8] Vinogradova, Yu.K. and Mayorov, S.R. (2012) Creation of "Black-Books" of Different Regional Levels. DNA and Genome Day. BITs 3rd Annual World. Milestones of the Great Bioindustry, 25-28 April 2012, Xi'an, 111.

[9] Vinogradova, Yu.K., Tkacheva, E.V. and Mayorov, S.R. (2012) About Flowering Biology of Alien Species: Lupinus polyphyllus Lindl. Russian Journal of Biological Invasions, 3, 163 171.

[10] Tkacheva, E.V., Vinogradova, Yu.K. and Pavlova, I.V. (2011) Variability of Morphometric Characteristics of Galega orientalis Lam. in Some Populations of Natural and Secondary Ranges. Russian Journal of Biological Invasions, 2, 268-272.

[11] Vinogradova, Yu.K., Tkacheva, E.V., Brindza, J., Mayorov, S.R. and Ostrowsky, R. (2013) On flowering patterns of alien species: 2. Robinia pseudoacacia, $R \times$ ambigua, and $R$. neomexicana. Russian Journal of Biological Invasions, 4, 74-86.

[12] Kuklina, A.G., Vinogradova, Yu.K. and Tkacheva, E.V. (2015) About Flowering Biology of Alien Species: Caragana arborescens Lam. and C. laeta Kom. Russian Journal of Biological Invasions, 6, 238-251. http://dx.doi.org/10.1134/S2075111715040037

[13] Blossey, B. and Notzold, R. (1995) Evolution of Increased Competitive Ability in Invasive Nonindigenous Species: A Hypothesis. Journal of Ecology, 83, 887-889. http://dx.doi.org/10.2307/2261425

[14] Hufbauer, R.A. and Torchin, M.E. (2007) Integrating Ecological and Evolutionary Theory of Biological Invasions. Ecological Studies, 193, 79-95.

[15] Vinogradova, Yu.K. (1992) Microevolution Processes in Adventive and Introduced Plants. Abstract of a Doctor of Science Thesis (in Russian). Moscow, 1-40. 
Submit or recommend next manuscript to SCIRP and we will provide best service for you:

Accepting pre-submission inquiries through Email, Facebook, LinkedIn, Twitter, etc. A wide selection of journals (inclusive of 9 subjects, more than 200 journals)

Providing 24-hour high-quality service

User-friendly online submission system

Fair and swift peer-review system

Efficient typesetting and proofreading procedure

Display of the result of downloads and visits, as well as the number of cited articles

Maximum dissemination of your research work

Submit your manuscript at: http://papersubmission.scirp.org/

Or contact ajps@scirp.org 